\title{
The emergence of coronavirus and contemporary socio-environmental challenges
}

\author{
Leandro Luiz Giatti \\ Mariana Gutierres Arteiro da Paz \\ Renata Ferraz de Toledo \\ Zenaida Luisa Lauda-Rodriguez \\ Beatriz Milz
}

(D) ${ }^{I}$ Environmental Health, Faculty of Public Health (FSP), University of São Paulo (USP)

São Paulo/SP - Brasil.

(D) Laboratory of Indicators for Sustainability at the Earth System Science Center, National Institute for Space Research (LADIS/ CCST/INPE)

São José dos Campo/SP - Brasil

(D) III Architecture and Urbanism, University São Judas Tadeu (USJT)

São Paulo/SP - Brasil

(D) IV Environmental Science (PROCAM), University of São Paulo (USP)

São Paulo/SP - Brasil

(D) ${ }^{V}$ Environmental Science (PROCAM), University of São Paulo (USP)

São Paulo/SP - Brasil
São Paulo. Vol. 23, 2020

Editorial

DOI: http://dx.doi.org/10.1590/1809-4422asoceditorialvu2020L4ED 
Connections, interdependencies and uncertainties are crucial elements in the historical moment in which we live. Unfortunately, this finding still gives much more by the size and complexity of emerging problems than by cooperation up to the search for a better and sustainable world. At the time of the writing of this editorial, in the beginning of May 2020, the most recent international public health emergency, the infection of humans and rampant spread of new coronavirus departing from Wuhan, China, testified about it.

In this sense, it is primarily a matter of speculation as to the possible origin, as indicated, that the virus may have bats as original hosts. In the field of socio-environmental relations that lead us to dialogue, if this speculation is found, this may be another emerging disease associated with environmental impacts, habitat reduction and indiscriminate exploitation of fauna resources. This clearly demands an understanding of the inseparability between human, animal and environmental health, in what has been called One Health ${ }^{1}$, in the perspective of integrating programs such as food security, zoonosis control, among others, and producing multisectoral responses to possible risks. In other words, demands a holistic understanding of a disease that may have originated from the departure of a virus from its ecosystem, facilitated by intrinsic social interactions in the search for resources and food. The emergence or epidemic of diseases, resulting from some ecological imbalance is something that has already been experienced, in different ways and contexts, at other times, such as the introduction of the Ebola virus in the human population in the late 1970s; and waves of yellow fever outbreaks, which occurred in several regions of Brazil since 2017. This initial condition invites us to reflect, therefore, that an imbalance in an ecosystem can revert to a problem of global scope, this in a fast and strongly impacting manner.

The spreading rate of the coronavirus attests the connections between vulnerabilities and gains ground due to the global interdependence of trade, tourism and other ways that favor the spread of the consequences that accompany the transmission of the virus among human populations.

This characterizes systemic relationships of vulnerability, and the losses do not stop there, because even before the disease was considered a pandemic, it's economic impact has already occured, including, by the dynamics and connectivity of global financial markets. That is, the world stock markets already impacted notably on a cascade effect by the circumstances and contingencies strongly observed since China. In the beginning of March 2020, the economic impact, preceded by the surprisingly number of confirmed cases, was already being announced in northern Italy, in this case, with remarkable concern for activities associated with tourism.

In turn, the shutdown of various sectors in China, such as the industrial sector, and the reduction of internal flights to contain the coronavirus epidemic, among other synergistic factors, also led to a $25 \%$ reduction in greenhouse gas emissions, according 
to a study released by Carbon Brief2. In the first two weeks of February 2020, the drop in $\mathrm{CO} 2$ emissions, for example, approached 100 million tons, the equivalent to what Portugal emits in the period of 1 year.

In an interview for University of São Paulo Newspaper (Jornal da USP ${ }^{3}$ ), published at the end of January 2020, Professor Deisy Ventura, from the School of Public Health of the University of São Paulo, highlighted the importance of public health systems and the strengthening of scientific production so that it is possible to face an international emergency like this. In this regard, it should be noted that the declaration of the coronavirus as an international public health emergency, by the World Health Organization, refers to combining efforts, sharing information, aggregating research centers and skills, developing joint strategies and, all of this, within of an international cooperation process involving public health systems in 196 signatory countries. In this case, showing an opportunity to use connections and interdependencies for the common good, in a global context. This process of sophisticated international cooperation shows a fundamental advance, however, relatively recent because it has been current since 2007. However, despite its remarkable importance, the international public health emergency is a governance apparatus geared to consequences and not to causes, distant also of the anticipatory governance that global issues demand, considering the connections, interdependencies and uncertainties.

Returning to the socio-environmental argument, perhaps we should note that the current risks of profound impacts from deforestation in the Amazon, fires in Australia and global climate changes should also be treated as international emergencies, in a category that also dialogues with uncertainties, risks to human health and a wide range of systemic consequences. But notably, there are serious problems in adding efforts to environmental issues of scope or risk of global consequences. Also, of course, there is a profound difference between the organization and responsiveness towards prevention or emergency, the first being quite deficient. This is worrying, since often emergencies arise precisely from the lack of prevention.

Scientific production classically lays the foundations for preventive postures, studying through methods and objectivity the causal relationships and bringing clarification as to mechanisms that can, for example, lead to profound disruptions in socioenvironmental systems. So is the extensive scientific production associated with global climate change. Also it is with regard to the strong and grounded scientific knowledge attesting to the planetary importance of the Amazon. But in times of exacerbation of doubts, of false prophets and disillusionment with new and vicious forms of communication, the well-established and quality science has also been seriously discredited, even though its usefulness is routinely proven, as happened in partnership between professionals in the field of Brazilian health and scientists, which provided a rapid response at the peak of the Zika Virus epidemic, between the years 2015 and 2016. It is necessary to strengthen scientific production and discourse! But it is also essential to promote dialogue between academia and society, within the context of the current forms of digital communication.

2 - https://www.carbonbrief.org/analysis-coronavirus-has-temporarily-reduced-chinas-co2-emissions-by-a-quarter

3 - https://jornal.usp.br/artigos/coronavirus-nao-existe-seguranca-sem-acesso-universal-a-saude 
In addition, to face the challenges of preventing disasters and acting on emergencies, it is necessary to strengthen science and expand its interaction with the society, preferably through reflective and participatory mechanisms. Fundamentally, this science we demand must be maintained by public funding, thus ensuring the link with legitimate demands of society, without risk of conflict of interests, mitigating threats and reducing the possibility of bias. Scientific knowledge, legitimized in this way, in association with the disclosure of true information and in a transparent manner, must be the basis for emergency prevention and care systems, and its potentialities must raise a global dialogue within this phenomenology of similar scale.

After this brief reflection on the impacts and challenges represented by the spread of COVID-19 around the world for health systems at all scales, especially at the global level, we invite everyone to read the new articles published corresponding to the Annual Volume of 2020. As always, we would like to thank the entire editorial team of Revista Ambiente \& Sociedade for their fundamental contribution to ensure the continuity of the publication.

Opening this new group, as original articles, the authors Celso Barbiéri and Tiago Mauricio Francoy, in the work Theoretical model for interdisciplinary analysis of human activities: Meliponiculture as an activity that promotes sustainability, propose a theoretical model to analyze meliponiculture dealing with the environmental cultural, social and economic domains. They conclude that such activity should be encouraged through participatory and interdisciplinary public policies, integrating the various actors involved.

In the article: Urban Ecosystem Services: Carbon fixation in the Permanent Preservation Areas of Campinas-SP, the authors Rodrigo Semeria Ruschel and Antônio Carlos Demanboro, using a methodology based on the use of allometric equations to calculate the above-ground dry biomass, concluded that in addition to carbon fixation, the recovery of permanent preservation areas from water courses provides additional ecosystem services, which, when contemplated in the cost-benefit analysis of projects, represent the majority of the total benefits.

Through a case study on the Columbia River Basin (BRC), shared by the United States and Canada, whose waters drain into the Pacific Ocean, the author Armando Gallo Yahn Filho demonstrated the impossibility of implementing Integrated Water Resources Management in BRC, although there is multilevel governance that allows cooperation between the United States and Canada; in the article: Multi-level water governance without integrated water resources management (IWRM): cooperation in the Columbia River Basin.

The authors Natália Anseloni Nista, Celeste Aída Sirotheau Corrêa Jannuzzi, Orandi Mina Falsarella and Samuel Carvalho De Benedicto, addressing different philosophical approaches related to animals, their rights and how they fit into the discussion of sustainable development, conclude that it is possible to observe a progressive concern with the habitat of animals with a broader view of them in general and in different contexts; in the article Society and sustainable development: Animal rights in sustainability discourse. 
In the article: Synthetic biology and genetic manipulation: risks, promises and responsibilities, the authors Roberto Rohregger, Anor Sganzerla and Daiane Priscila SimãoSilva investigate, from a bioethical perspective, about the benefits, risks and threats to life, resulting from production, manipulation and creation of synthesized DNA's. They conclude that the achievements of synthetic biology have been shown to be ambivalent, because hopes are mixed with the threats, with unpredictable results to the diversity of life in the biosphere, which makes prudence the virtue par excellence.

Through an evaluation of the functioning of Sewage Treatment Plants and their influence on the quality of life of the population of Parelhas and Pedro Velho, the authors Douglisnilson de Morais Ferreira, Julio Alejandro Navoni, André Luis Calado Araújo and Viviane Souza do Amaral, in article Risk perception of populations in Northeastern Brazil about domestic sewage treatment and reuse, found great rejection in the operation of the stations associated with the odor and proliferation of mosquitoes, which result in economic, social and public health problems.

The authors Érico L. Pagotto and Sylmara Lopes Francelino Gonçalves-Dias, based on the theory of the fields, analyze the process of building public policies for sustainable production and consumption in Brazil after the country joined the Marrakesh Process in 2003. They note that a series of obstacles have been causing delays in advancing the policy of sustainable production and consumption due to disputes between incumbent and challenging actors; in the article: Sustainable production and consumption: a study on strategic field action theory.

In the article: Sustainability assessment of the Jari Valley- Amapá - Amazon: Laranjal and Vitória do Jari, the authors José Francisco de Carvalho Ferreira, Jacklinne Corrêa Matta and Jodival Maurício Costa, using indicators collected from official sources, treated and standardized by their own methodology, sought to assess the levels of sustainability of Laranjal and Vitória do Jari. The results indicate that the two municipalities have poor performances that compromise their municipal sustainability towards the 2030 Agenda.

Taking a sample of teachers from four rural schools in Bogotá, the authors Carlos Julio Galvis-Riaño, Francisco Javier Perales-Palacios and Yolanda Ladino-Ospina, characterized the conceptions of Environment and Environmental Education (EA) and found that educators have different ways of approaching the environmental issue, observing a strong tendency to assume the environment and EA as a biological and conservationist issue. In the article: Conceptions about environment and environmental education by teachers from rural schools in Bogotá - Colombia.

In the article: Ecosystem-based Adaptation in Ecuador: good practices for Adaptive Co-Management, the authors Pere Ariza-Montobbio and Nicolás Cuvi designed and applied a multi-criteria methodology in five phases, to identify, characterize, select and evaluate Adaptive Co-Management and the conditions that limit or enhance it in the actions of Adaptation Based on Ecosystems. They found that planning and governance under a landscape approach, recognizing the diversity of contexts, promotes dialogue, cooperation and institutional innovation.

In order to evaluate the quality of well water and health risk scenarios, the authors 
Ana Celia Goes Melo Soares, Rômulo André Santos Silva, Carla Viviane Freitas de Jesus, Roneval Felix Santana, Álvaro Silva Lima, Sonia Oliveira Lima and Maria Nogueira Marques, in the article: Water and health risk assessment in the Aracaju Expansion Zone - SE, sampled the water according to the methodology established by the Standard Methods for the Examination of Water \& Wastewater and concluded that the rainy season presented contamination by bacteria, while in the dry season most samples did not show bacteriological count.

Finally, the authors Mariana Gutierres Arteiro da Paz and Ana Paula Fracalanza, in the article: Social control in basic sanitation at Guarulhos (SP): the Municipal Council of Urban Policies, evaluated the incorporation of the theme of basic sanitation in the Municipal Council of Urban Policies of Guarulhos, Sao Paulo, as well as participation in the area according to the precepts of environmental justice and water governance. They conclude that the way in which the Council was empowered to deal with issues of basic sanitation did not favor the social construction of the process.

We wish you all a good reading! 


\section{Leandro Luiz Giatti}

■lgiatti@usp.br

ORCiD: https://orcid.org/0000-0003-1154-6503

Mariana Gutierres Arteiro da Paz

ORCiD: https://orcid.org/0000-0003-3055-61847

Renata Ferraz de Toledo

ORCiD: https://orcid.org/0000-0002-4770-7842

\section{Zenaida Luisa Lauda-Rodriguez}

ORCiD: https://orcid.org/0000-0003-2432-0255

\section{Beatriz Milz}

ORCiD: https://orcid.org/0000-0002-3064-4486

How to cite: GIATTI, L. L. et al. Editorial - The emergence of coronavirus and contemporary socio-environmental challenges. Ambiente $\mathbb{\&}$ Sociedade. São Paulo, v. 23, p. 1-7, 2020. 